Article

\title{
Geochemical Processes Controlling Ionic Composition of Water in the Catchments of Lakes Saana and Saanalampi in the Kilpisjärvi Area of North Scandinavia
}

\author{
Valle Raidla ${ }^{1, *\left(\mathbb{D}, \text { Enn Kaup }^{2} \text {, Sigrid Hade }\right.}{ }^{1}$, Jüri Ivask ${ }^{2}$ and Alvar Soesoo $^{1}$ \\ 1 Geological Survey of Estonia, Department of Hydrogeology and Environmental Geology, Kreutzwaldi 5, \\ 44314 Rakvere, Estonia; Sigrid.Hade@egt.ee (S.H.); Alvar.Soesoo@egt.ee (A.S.) \\ 2 Department of Geology, Tallinn University of Technology, Ehitajate tee 5, 19086 Tallinn, Estonia; \\ enn.kaup@ttu.ee (E.K.); Juri.Ivask@ttu.ee (J.I.) \\ * Correspondence: valle.raidla@egt.ee
}

Received: 14 March 2019; Accepted: 12 April 2019; Published: 16 April 2019

\begin{abstract}
The study focuses on chemical composition of stream and subsurface water in the catchments of two small arctic alpine lakes in the Kilpisjärvi area (northwest Finland). Differences and changes in chemical components of both water types are followed in order to detect spatial variability and impact of environmental factors. To achieve this, ion compositions of subsurface water and streams were measured at 12 sites in the catchments of Lakes Saana and Saanalampi during four years (2008-2010, and again in 2017). In the Lake Saanalampi catchment, the salinity of stream water $\left(7.0\right.$ to $\left.12.7 \mu \mathrm{S} \cdot \mathrm{cm}^{-1}\right)$ corresponded to that of snow. In the catchment of Lake Saana, however, the conductivity in stream water was much higher ( 40 to $220 \mu \mathrm{S} \cdot \mathrm{cm}^{-1}$ ), connected mainly to the increase of $\mathrm{SO}_{4}{ }^{2-}$ and less with $\mathrm{Mg}^{2+}$ and $\mathrm{Ca}^{2+}$ contents, especially in the western part of the Saana catchment. These results demonstrate that arctic conditions do not preclude intense chemical weathering where conditions are favourable. Although chemical composition of the soil fluid does not match the geochemical signal from the local soil, rock composition, especially the presence of pyrite, is the main controller of chemical weathering rates of the rocks on the area. This supports earlier views that the character of precipitation mostly controls water chemistry of local lakes in the Kilpisjärvi area.
\end{abstract}

Keywords: Arctic conditions; stream water chemistry; pyrite oxidation; weathering

\section{Introduction}

The intensity of weathering is mainly controlled by root respiration and degradation of soil organic matter [1-5], which in most cases are connected to $\mathrm{CO}_{2}$ content in the water and the aggression of $\mathrm{H}_{2} \mathrm{CO}_{3}$ on the rock matrix. In cold areas, vegetation activity is limited [6] and, therefore, abiotic factors such as temperature amplitude, water availability or rock-type variations in local landscape become more important [7-14]. Despite the rock's weathering rate remaining a magnitude lower in cold areas than in the tropics or in temperate regions $[12,15]$, it is still significantly higher than the chemical signal from local precipitation [8,16-18].

The Kilpisjärvi area is a sparsely populated region in northwest Finland and has weak local and regional human impact. Therefore, it offers a variety of research possibilities such as the natural evolution of geotopes or global impact on this relatively isolated area. Several short low-pH periods in the lakes of the Kilpisjärvi area have been registered, which have been tied to the early spring melt period when $\mathrm{pH}$ in the lakes can drop below 6 [19]. The period only lasts a few days and its environmental influence is weak $[19,20]$. Such acidic pulse in spring has been observed in many lakes 
and rivers of northern Europe and north-eastern United States and the phenomenon has typically been connected with sulphate and nitrate release as a result of acidic deposition from anthropogenic sources [21-24]. On the other hand, Laudon et al. [25] and Caritat et al. [26] pointed out that substantial $\mathrm{pH}$ decline during spring melt episodes is a natural feature of a boreal ecosystem and not only the result of acidic deposition. Indeed, different studies have shown that nitrate and sulphate concentrations in snow on the Kilpisjärvi area are quite low [19,27], suggesting that anthropogenic sources are of marginal proportion. Raidla et al. [27] argued that $\mathrm{pH}$ in snow is controlled by the dissolved $\mathrm{CO}_{2}$ and carbonate dust rather than by $\mathrm{SO}_{4}{ }^{2-}$ or $\mathrm{NO}_{3}{ }^{-}$. Although the research showed complicated relations between $\mathrm{NO}_{3}{ }^{-}$and the snow $\mathrm{pH}$, the reason for this has not definitively been clarified.

Nevertheless, Korhola et al. [28] observed that in Lake Saana, sediments of all the C, N and S profiles taken from the bottom of the core show lower values, which could be a sign of lower industrial impact before the Industrial Revolution. The less evident increase in the sulphur profile could be explained by local sulphur input from the surface carried to the lake by runoff. The Kilpisjärvi area is geochemically and mineralogically heterogeneous and strongly tectonized. It could be that some of the sulphur has derived from tectonic zones, which often contain sulphide minerals such as pyrite [29].

Several studies have shown that the highest weathering rates occur in soils that contain high concentrations of sulphide minerals [30-34] and where sulphide oxidation results in the formation of sulphuric acid, an even stronger weathering agent than carbonic acid. The outcropping rock sections in the Lake Saana catchment provide a good possibility to trace the effects of different abiotic processes on the chemistry of local surface and subsurface water.

The aim of the current study is to determine the presence of pyrite in the Kilpisjärvi area and its impact on weathering processes, and through this, also on the local environment. The study focuses on spatial differences of chemical components in the drainage water from the Lake Saana catchment and its surroundings as a proxy for rock weathering in order to determine chemical weathering processes and rates. Additionally, samples were collected from the catchment of the small Lake Saanalampi, located in a different geological situation.

\section{The Study Area}

The Kilpisjärvi region is located approximately $120 \mathrm{~km}$ from the Arctic Ocean, in north-western part of the Finnish Lapland (Figure 1a), in the transition zone between the North Atlantic oceanic climate and the Eurasian continental climate [35]. The annual average air temperature is $-2.4{ }^{\circ} \mathrm{C}$, but in higher altitudes in the valleys between the mountains, the climate can be even colder. The annual mean precipitation is ca. $430 \mathrm{~mm}$, while the annual evapotranspiration is approximately $100 \mathrm{~mm}$ [36]. Sixty per cent of the precipitation falls as snow in the period from October-May, the maximum falling in July $(60 \mathrm{~mm}$ ). Heavy rainfall events (over $10 \mathrm{~mm}$ ) are unusual. Surface water runoff is minimal, except during the spring melt period when heavy floods are common in mid-May [20].

The study area has an altitude of $400-1000 \mathrm{~m}$ a.s.l. on the eastern thrust-front zone of the Scandinavian Caledonide nappes, where Lower Paleozoic quartzite, claystone, dolomite and conglomerate layers are overlain by 2.8-billion-year-old crystalline bedrock complexes [37]. The principal stratigraphy of the thrust front can be followed in detail in the south-southeast facing cliffs of Mount Saana (Figure 1b). The overthrusting unit in the area is composed of Saana arkose quarzite (Nalganas nappe), Cambrian Jerta dolomite and silicate claystone (Jerta nappe). The silicate claystone or clayey slates are the lowermost units across the territory of Mount Saana. The claystones are overlain by dolomites, which seem to be not horizontal, but tilting from southeast to northwest. The uppermost nappe portion consists of hard arkose quartzite, which protects the lower layers from erosion. The basement is Neo-Archaean in age and consists mainly of metamorphosed granodioritic-granitic-quartz-dioritic rocks with addition of basaltic to andesitic volcanic rocks (Figure 1). 


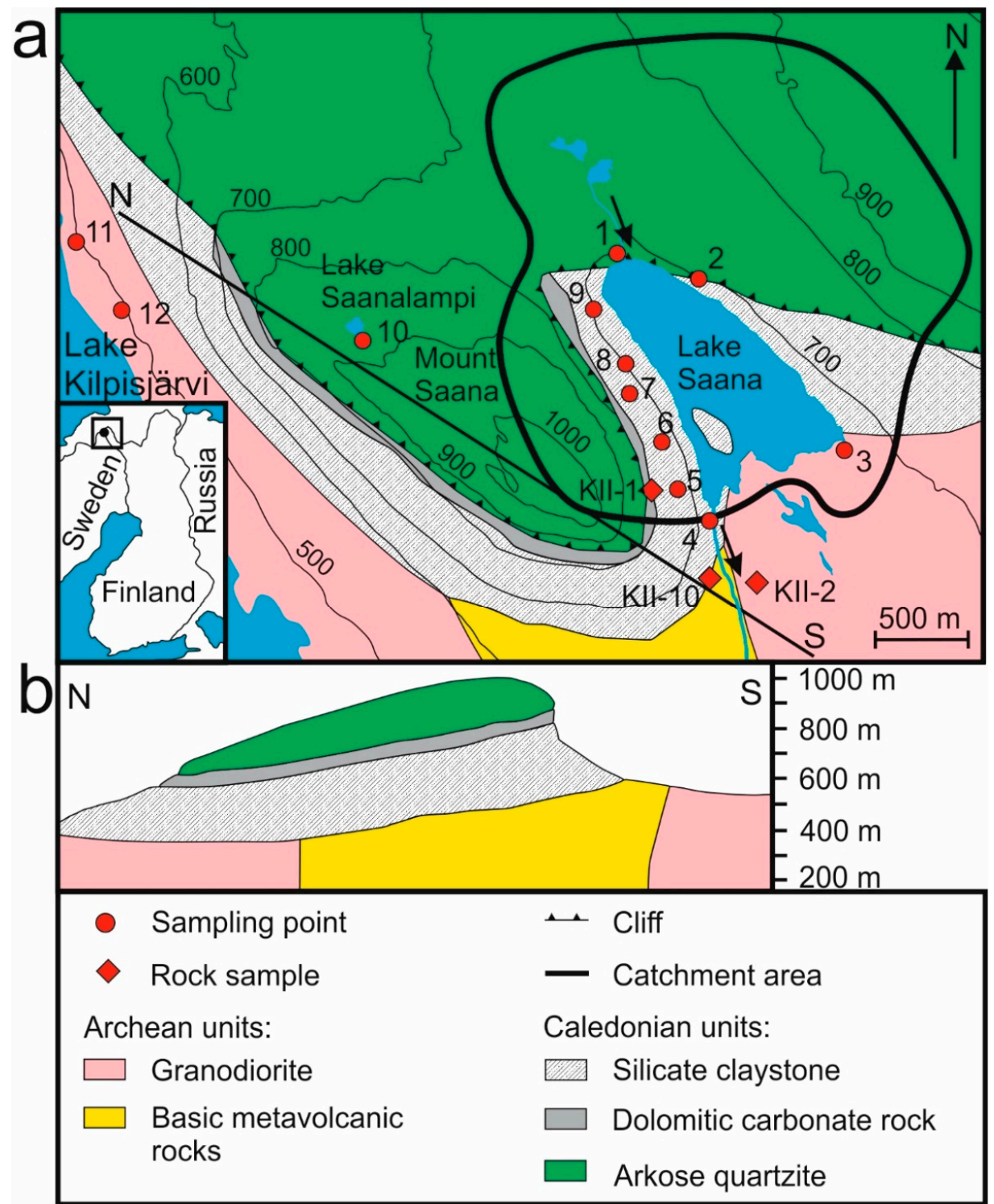

Figure 1. A schematic map of Lake Saana and Saanalampi catchments showing the positions of sampling points (a) and the cross-sections from northwest to southeast (b).

Local tundra soils are characterised by extreme conditions such as long periods of low temperatures, relatively large annual temperature variation and multiple episodes of freezing and thawing during spring and autumn. Due to cool climate the soil is weakly developed, covered by just a thin humus layer on the Quaternary sediments, while bare rock surfaces and rock piles prevail (Figure 2). The Fennoscandian tundra differs from the Arctic tundra of Canada and Siberia by the absence of continuous permafrost [38]. The permafrost phenomenon in the area is represented only by the so-called palsas. The latter are distinctive to sporadic permafrost regions of Arctic wetlands, which contain a perennially frozen core of peat or till with maximum depth of up to $4 \mathrm{~m}$ and lateral extent at least $30 \mathrm{~m}$ [39]. The bedrock permafrost with the thickness of at least $50 \mathrm{~m}$ has been registered at the top of Mount Saana (over $880 \mathrm{~m}$ a.s.l.) [40]. On the other hand, Vanhala et al., [41] have also observed continuous permafrost at Mount Halti (about $25 \mathrm{~km}$ NE from Mount Saana), but only above $1030 \mathrm{~m}$ a.s.l. 


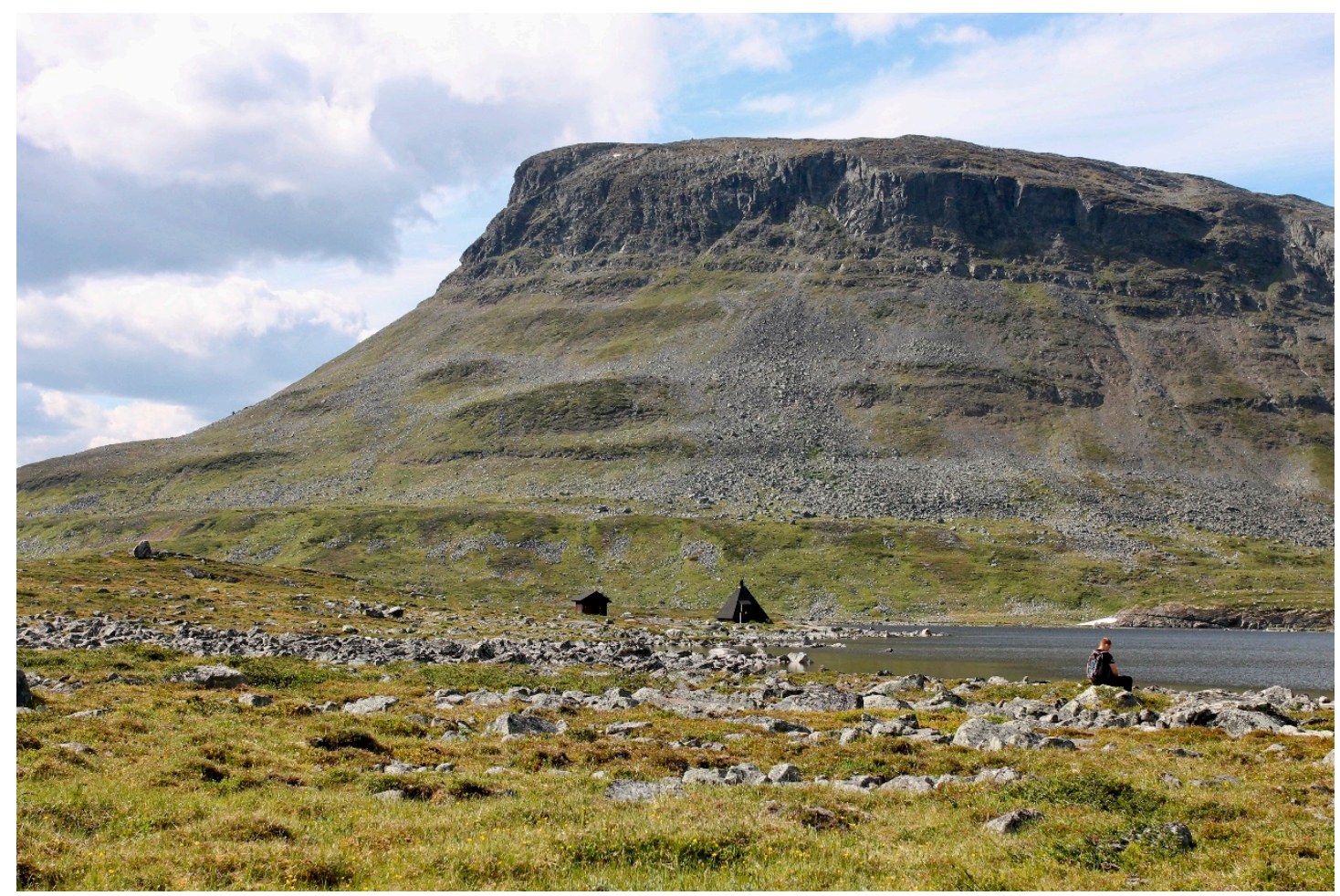

Figure 2. View from the south of Lake Saana to Mount Saana.

Lake Saana $\left(69^{\circ} 05^{\prime} \mathrm{N}, 20^{\circ} 87^{\prime} \mathrm{E}\right)$ is located between two fells in the treeless tundra at $680 \mathrm{~m}$ a.s.l. The lake's surface area is $62 \mathrm{ha}$ and maximum depth is $24 \mathrm{~m}$. Subalpine vegetation and bare rock surfaces cover the lake's catchment (460 ha) [20]. The southeast part of the catchment is mostly flat and marshy (Figure 3). The streams whose length is limited to $500 \mathrm{~m}$ by the small size of the valley are shallow and, except for the northern inflow, mostly fed by melting snow in spring and dry out during summer (in August). The northern inflow forms a well-defined bed with the depth 0.4 to $1.0 \mathrm{~m}$ (Figure 1a) and contributes substantially to the flow that drains flat marshy areas.

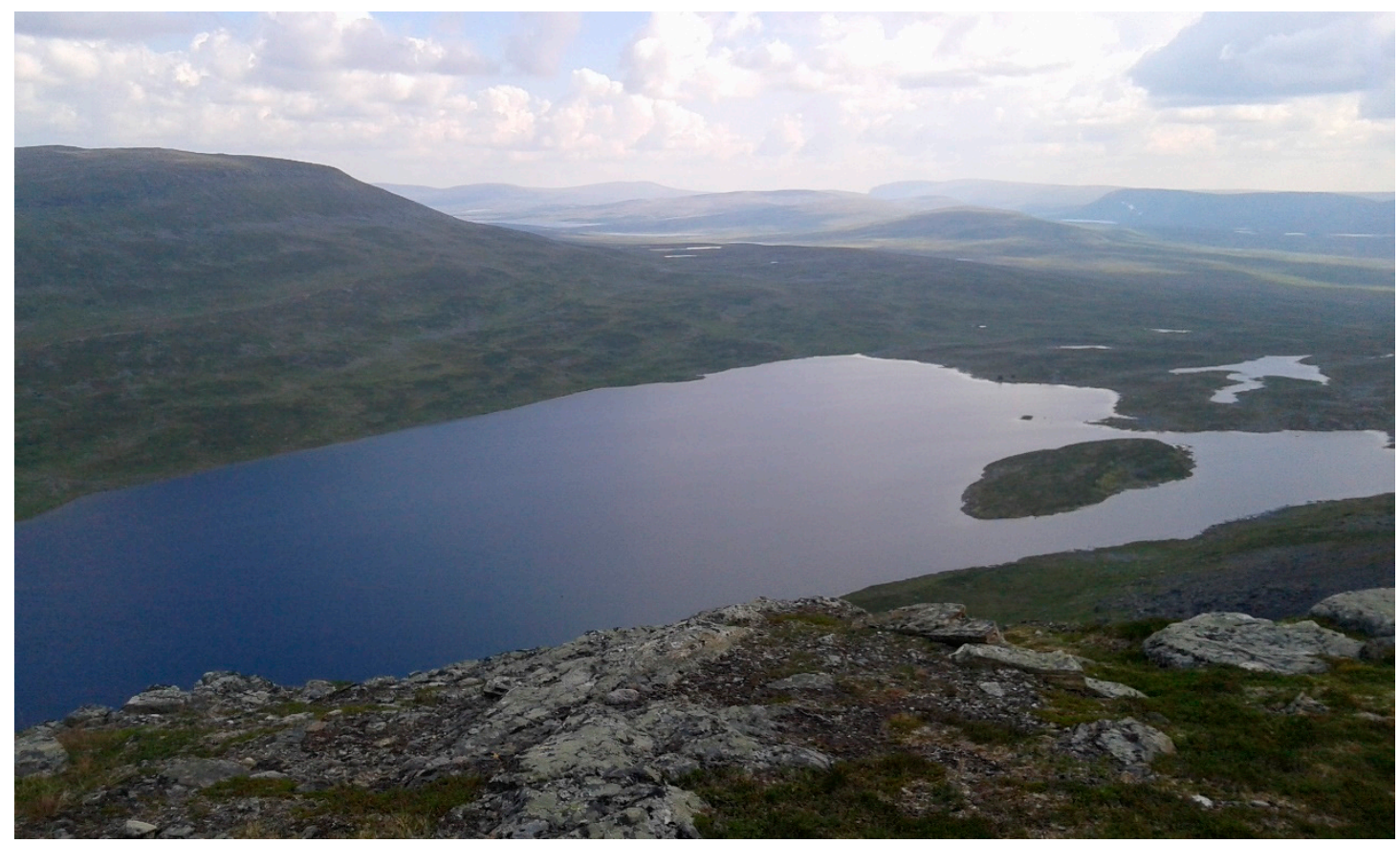

Figure 3. View of central and south part of Lake Saana from top of Mount Saana. 
Lake Saanalampi $\left(69^{\circ} 02^{\prime} \mathrm{N}, 20^{\circ} 49^{\prime} \mathrm{E}\right)$ is a small lake on the northern slope of Mount Saana, at $865 \mathrm{~m}$ a.s.l. The lake is $120 \mathrm{~m}$ long and $80 \mathrm{~m}$ wide with steep and rocky shores. Lake Saanalampi has an outflow in the north and some inflows in the south, which drain from the upper part of Mount Saana.

\section{Material and Methods}

Water and rock samples used in this study were collected in the Lake Saana catchment or in its vicinity from 2008-2010 and in 2017. Rock samples were either taken straight from the outcrops or from Quaternary drill cores at depths of $0.1-1 \mathrm{~m}$. The water samples were collected directly from streams and subsurface water close to the streams at 12 sites, using ceramic-tipped plastic tubes that were dipped into drill holes at depths of $0.5-2 \mathrm{~m}$. Tops of tubes were promptly covered with plastic foils in order to avoid evaporation, precipitation and contamination of the samples. The tubes were emptied several times before water samples were taken in order to obtain the freshest infiltrated water for measurements. The water was pumped into sample bottles using a hand pump and keeping the tubes in their initial positions.

Temperature, electrical conductivity, $\mathrm{pH}$ and major ion content were determined for the collected water samples. $\mathrm{pH}$ and electrical conductivity were measured directly in the field with IQ170 Scientific Instruments field $\mathrm{pH}$ conductivity meter. The instrument was calibrated with $\mathrm{pH}$ buffers 4 and 7 . Major ions were measured on Dionex ICS-1000 ion chromatograph at the University of Tartu. For anion analyses, AS14A $4 \mathrm{~mm} \times 250 \mathrm{~mm}$ analytical column and AG14A $4 \mathrm{~mm} \times 50 \mathrm{~mm}$ guard column were used with $8.0 \mathrm{mM}$ sodium carbonate $/ 1.0 \mathrm{mM}$ sodium bicarbonate eluent at flow rate of $1 \mathrm{~mL} \mathrm{~min}{ }^{-1}$. For cation analyses, CS12A $4 \mathrm{~mm} \times 250 \mathrm{~mm}$ analytical column and CG12A $4 \mathrm{~mm} \times 50 \mathrm{~mm}$ guard

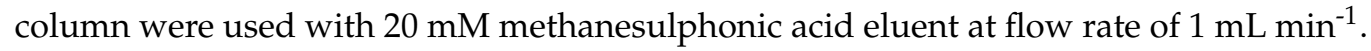

Major and trace element compositions of the subsoil as well as major rock types were analysed at the Department of Geology, Tallinn University of Technology, by X-ray fluorescence analysis (XRF). The samples were oven-dried at $105^{\circ} \mathrm{C}$ over $24 \mathrm{~h}$. For XRF analysis the samples were pulverized in a wolfram-cobalt ring mill. Loss on ignition (LOI) was determined from $1 \mathrm{~g}$ of pulverized sample material at $500{ }^{\circ} \mathrm{C}$ and $920^{\circ} \mathrm{C}$. For geochemical analysis, S4 Pioneer Spectrometer (Bruker AXS GmbH, Karlsruhe, Germany) with operation power of $3 \mathrm{~kW}$ was applied using an X-ray tube with a rhodium anode. The samples were measured according to the manufacturer's standard as MultiRes modification (pre-calibrated standardless method).

\section{Results and Discussion}

\subsection{Rock and Soil Composition}

The contact between Precambrian and Lower Paleozoic rock units can be found along the bank of a small brook close to the southern outflow of Lake Saana (Figure 1a). In places, the contact is heavily tectonized and the crushed rock usually mineralized. This part of the rock section cropping out on the slope of Mount Saana is probably the most exposed to weathering. The least vulnerable to weathering is arkose quartzite, which covers the sedimentary section. The Neo-Archaean basement is cut by a number of dykes which have very high iron content (up to $17 \mathrm{wt} \% \mathrm{Fe}_{2} \mathrm{O}_{3}$ ) but are relatively low in sulphur (up to $0.04 \mathrm{wt} \%$; Table 1). In comparison, higher sulphur content is characteristic of the claystone rocks ( $0.09 \mathrm{wt} \%$; Table 1$)$. Typically, the claystone outcrops on the slope of Mount Saana are covered with about $1 \mathrm{~mm}$ thick haematite layer. Additionally, limestone (predominantly dolomite; Figure 4a) is represented as a 20-30 m thick layer on the Mount Saana cliff in the western part of the catchment, but limestone debris is also widely spread at the foot of the mount.

Subsurface samples from the depths of 0.1 and $1 \mathrm{~m}$ collected from drill cores reflected the bedrock composition (Table 1). Quartz as the main component, plagioclase (more specifically-oligoclase) and amphibole as secondary minerals were found in all the samples. Traces of mica and chlorite were also present (Figure 4b; Supplementary A). Although sulphur contents in some subsurface samples are much higher than in rock samples, pyrite has not been detected there. The sulphur has a clear correlation with the LOI, which can refer to sulphur accumulations in the organic material (Table 1). 
Table 1. Chemical composition of rock and surface samples in the Lake Saana catchment.

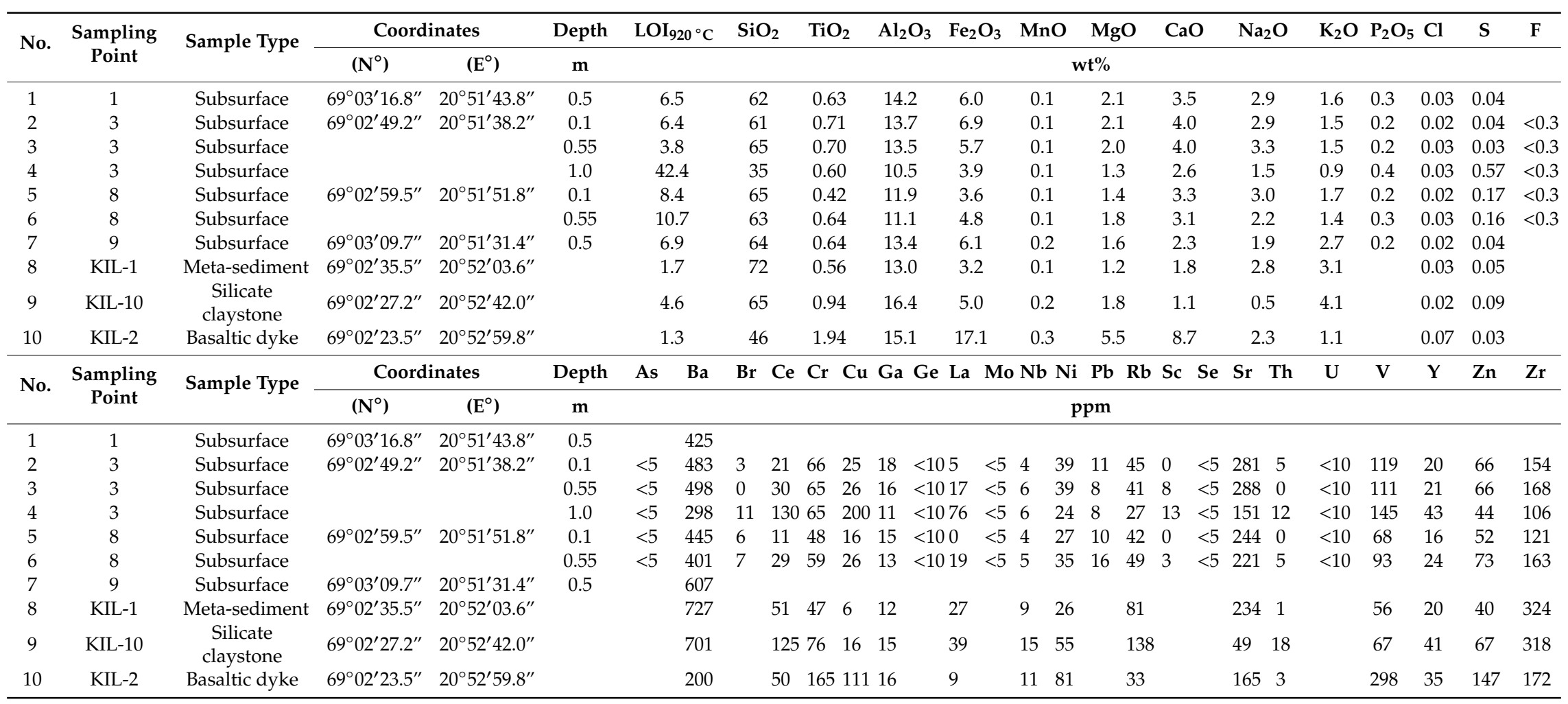




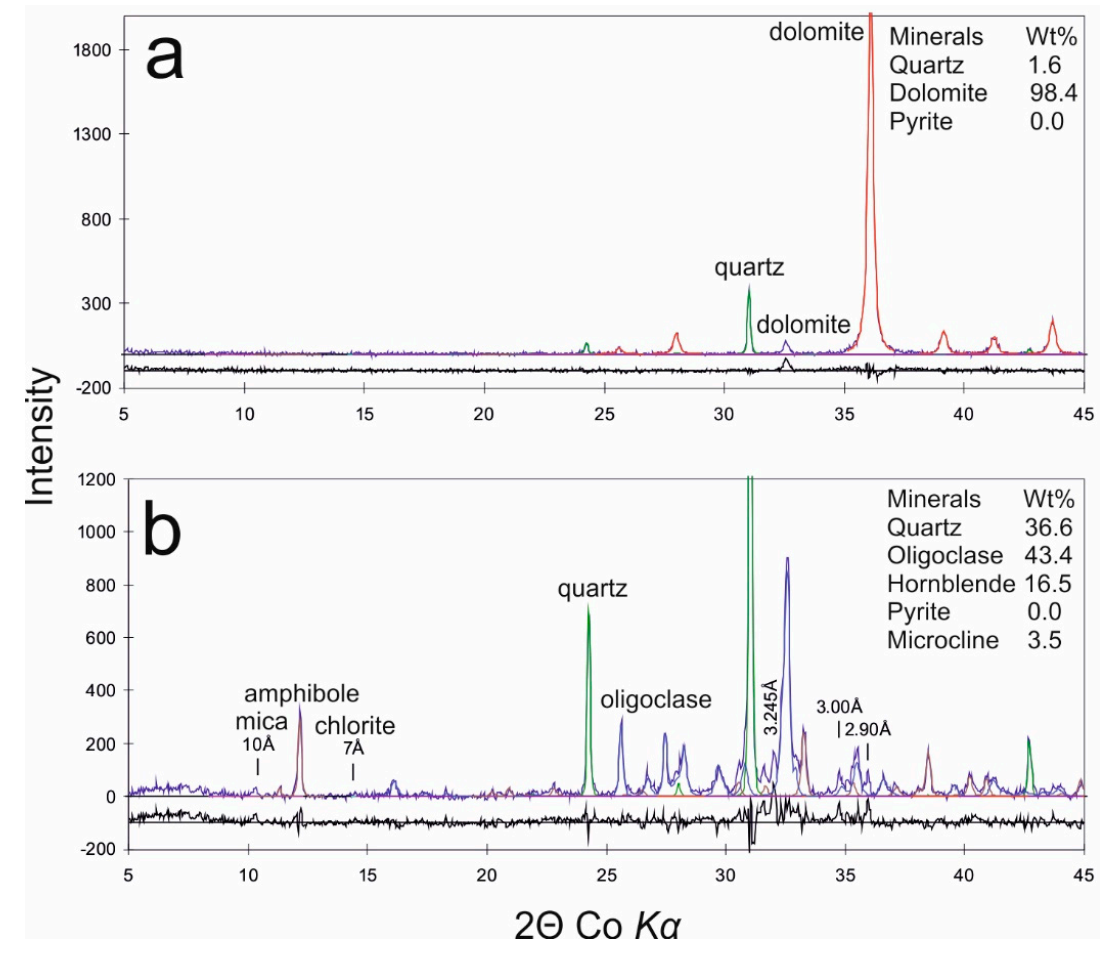

Figure 4. Representative XRD pattern of carbonate rock (a) and subsurface sample No. 3 (b) (Table 1).

\subsection{Salinity Fluctuation in Space and Time}

In the Lake Saanalampi catchment, the conductivity of stream water $\left(7.0\right.$ and $\left.12.7 \mu \mathrm{S} \cdot \mathrm{cm}^{-1}\right)$ corresponded to that of snow (about $5 \mu \mathrm{S} \cdot \mathrm{cm}^{-1}$ ) [27]. In the catchment of Lake Saana, however, the conductivity of stream water was much higher $\left(40\right.$ to $\left.220 \mu \mathrm{S} \cdot \mathrm{cm}^{-1}\right)$ and considerable differences in electrical conductivity were detected between eastern and western parts of the catchment (Figure 5a). The range of values of electrical conductivity of stream waters was like that of subsurface water, although the latter became saltier with depth (Table 2), which could indicate the waters' longer residence time and contact with the bedrock [34]. Differences in conductivity values measured in two years (Figure 5a) were seen most clearly in shallower subsurface water (Table 2). The conductivity fluctuations followed $\mathrm{Cl}^{-}$fluctuation in subsurface water and could be partly linked with the evaporative concentration because $\mathrm{Cl}^{-}$is practically missing in local soil (Table 1). Higher evaporation impact on subsurface water could have been the result of lower precipitation amount from April to June (130 mm in 2009 and $238 \mathrm{~mm}$ in 2010 ) and a higher temperature in summer 2009 compared to that of 2010 [42].

Higher electrical conductivity in both stream and subsurface water was mainly connected to the increase of $\mathrm{SO}_{4}{ }^{2-}$ content (Figure 6), especially in the western part of the Lake Saana catchment (sampling points 5 to 9). Additionally, chemical data from stream water show that higher $\mathrm{SO}_{4}{ }^{2-}$ content occurred in the western part of Mount Saana (sampling points 11 and 12 on Figure 1a; Table 3), which could point to a wider spread of sulphur containing minerals like gypsum or pyrite in the area $[31,43,44]$. Neither mineral was detected in surface or rock samples. Moreover, the content of $S$ was low in all subsurface samples (Table 1) and the sulphide mineral was visually noted only on a very limited area on the southwest part of the catchment. In the gypsum karst areas, the $\mathrm{pH}$ value of the water is slightly alkaline $(\mathrm{pH} \approx 7)$ but pyrite oxidation can lower $\mathrm{pH}$ significantly [45]. Although acidic $\mathrm{pH}$ values have been registered on the Lake Saana catchment they are not connected with higher $\mathrm{SO}_{4}{ }^{2-}$ contents in water, however, these results do not exclude the presence of pyrite. Dissolution of carbonate minerals like dolomite can quickly neutralize the acidity produced by sulphide oxidation and the chemical weathering budget of the watershed becomes controlled by the carbonate mineral reactivity $[30,34]$. 
Table 2. Chemical composition of subsurface water in the Lake Saana catchment in 2009 and 2010.

\begin{tabular}{|c|c|c|c|c|c|c|c|c|c|c|c|c|c|}
\hline \multirow{2}{*}{ No. } & \multirow{2}{*}{$\begin{array}{l}\text { Sampling } \\
\text { Point }\end{array}$} & \multirow{2}{*}{ Date } & \multirow{2}{*}{$\begin{array}{c}\text { Depth } \\
\mathrm{m}\end{array}$} & \multicolumn{2}{|c|}{ Coordinates } & \multirow{2}{*}{$\mathrm{pH}$} & \multirow{2}{*}{$\begin{array}{c}\text { El.cond. } \\
\mu S \cdot \mathrm{cm}^{-1}\end{array}$} & $\mathrm{SO}_{4}{ }^{2-}$ & $\mathrm{Cl}^{-}$ & $\mathrm{Na}^{+}$ & $\mathrm{K}^{+}$ & $\mathrm{Ca}^{2+}$ & $\mathrm{Mg}^{2+}$ \\
\hline & & & & $\left(\mathrm{N}^{\circ}\right)$ & $\left(\mathrm{E}^{\circ}\right)$ & & & \multicolumn{6}{|c|}{$\mathrm{mg} \cdot \mathrm{L}^{-1}$} \\
\hline 1 & 1 & 30 June 2010 & 0.5 & $69^{\circ} 03^{\prime} 16.8^{\prime \prime}$ & $20^{\circ} 51^{\prime} 43.8^{\prime \prime}$ & 6.3 & 47.8 & 6.5 & 0.7 & 1.4 & 0.6 & 4.5 & 1.4 \\
\hline 2 & 1 & 17 July 2009 & 1 & & & & & 11.2 & 3.4 & 6.5 & 3.2 & 10.5 & 4.9 \\
\hline 3 & 1 & 30 June 2010 & 1 & & & 6.8 & 95.6 & 14.3 & 1.4 & 3.1 & 1.5 & 9.8 & 3.7 \\
\hline 4 & 2 & 17 July 2009 & 1 & $69^{\circ} 03^{\prime} 14.3^{\prime \prime}$ & $20^{\circ} 52^{\prime} 07.3^{\prime \prime}$ & & 100.1 & 7.9 & 8.6 & 4.7 & 2.0 & 12.2 & 7.7 \\
\hline 5 & 2 & 05 July 2010 & 1 & & & 7.2 & 73.3 & 5.4 & 0.7 & 1.3 & 0.7 & 7.7 & 3.9 \\
\hline 8 & 3 & 30 June 2010 & 0.5 & $69^{\circ} 02^{\prime} 49.2^{\prime \prime}$ & ' $20^{\circ} 51^{\prime} 38.2^{\prime \prime}$ & 6.4 & 30.6 & 0.9 & 0.7 & 1.7 & 0.8 & 2.0 & 1.3 \\
\hline 6 & 3 & 17 July 2009 & 1 & & & & 167.2 & 2.0 & 3.1 & 8.6 & 1.9 & 19.1 & 17.9 \\
\hline 7 & 3 & 30 June 2010 & 1 & & & 6.3 & 47.1 & 2.4 & 0.7 & 2.8 & 1.2 & 3.4 & 2.3 \\
\hline 9 & 8 & 17 July 2009 & 1 & $69^{\circ} 02^{\prime} 59.5^{\prime \prime}$ & $20^{\circ} 51^{\prime} 51.8^{\prime \prime}$ & & 75.1 & 3.6 & 1.8 & 2.9 & 0.5 & 7.5 & 5.6 \\
\hline 10 & 8 & 05 July 2010 & 1 & & & 6.4 & 68.9 & 2.4 & 1.0 & 1.9 & 0.3 & 5.8 & 4.2 \\
\hline 11 & 8 & 17 July 2009 & 2 & & & & 128.4 & 54.3 & 1.4 & 4.2 & 4.1 & 12.9 & 12.7 \\
\hline 12 & 8 & 05 July 2010 & 2 & & & 6.3 & 131.7 & 48.6 & 1.0 & 2.7 & 1.6 & 11.2 & 8.7 \\
\hline 13 & 9 & 17 July 2009 & 1 & $69^{\circ} 03^{\prime} 09.7^{\prime \prime}$ & ' $20^{\circ} 51^{\prime} 31.4^{\prime \prime}$ & & 230.0 & 112.1 & 3.2 & 6.2 & 3.8 & 25.4 & 26.8 \\
\hline 14 & 9 & 05 July 2010 & 1 & & & 7.4 & 170.2 & 69.7 & 1.0 & 2.5 & 1.3 & 14.8 & 13.5 \\
\hline
\end{tabular}

Table 3. Chemical composition of streams in the Kilpisjärvi area in 2008, 2009, 2010 and 2017.

\begin{tabular}{|c|c|c|c|c|c|c|c|c|c|c|c|c|}
\hline \multirow{2}{*}{ No. } & \multirow{2}{*}{$\begin{array}{l}\text { Sampling } \\
\text { Point }\end{array}$} & \multirow{2}{*}{ Date } & \multicolumn{2}{|c|}{ Coordinates } & \multirow{2}{*}{$\mathrm{pH}$} & \multirow{2}{*}{$\begin{array}{l}\text { El.cond. } \\
\mu S \cdot \mathrm{cm}^{-1}\end{array}$} & $\mathrm{SO}_{4}{ }^{2-}$ & $\mathrm{Cl}^{-}$ & $\mathrm{Na}^{+}$ & $\mathrm{K}^{+}$ & $\mathrm{Ca}^{2+}$ & $\mathrm{Mg}^{2+}$ \\
\hline & & & $\left(\mathrm{N}^{\circ}\right)$ & $\left(\mathrm{E}^{\circ}\right)$ & & & \multicolumn{6}{|c|}{$\mathrm{mg} \cdot \mathrm{L}^{-1}$} \\
\hline 1 & 1 & 11 August 2008 & $69^{\circ} 03^{\prime} 16.8^{\prime \prime}$ & $20^{\circ} 51^{\prime} 43.8^{\prime \prime}$ & 6.4 & 29.6 & 0.7 & 1.1 & 0.3 & 0.1 & 0.1 & 0.1 \\
\hline 2 & 1 & 17 July 2009 & & & 7.6 & 44.8 & 6.5 & 1.0 & 1.9 & 0.4 & 9.7 & 1.2 \\
\hline 3 & 1 & 05 July 2010 & & & 7.5 & 36.5 & 5.3 & 0.9 & 1.8 & 0.3 & 6.7 & 0.7 \\
\hline 4 & 3 & 17 July 2009 & $69^{\circ} 02^{\prime} 49.2^{\prime \prime}$ & $20^{\circ} 51^{\prime} 38.2^{\prime \prime}$ & & 37.5 & 3.3 & 1.2 & 2.2 & 0.4 & 7.1 & 1.4 \\
\hline 5 & 3 & 05 July 2010 & & & 7.2 & 25.1 & 2.2 & 0.7 & 1.4 & 0.5 & 3.4 & 0.7 \\
\hline 6 & 5 & 26 July 2017 & $69^{\circ} 02^{\prime} 35.9^{\prime \prime}$ & $20^{\circ} 52^{\prime} 11.8^{\prime \prime}$ & 7.9 & 98.3 & 21.0 & 0.1 & 1.4 & 1.3 & 10.0 & 3.8 \\
\hline 7 & 6 & 26 July 2017 & $69^{\circ} 02^{\prime} 45.9^{\prime \prime}$ & $20^{\circ} 52^{\prime} 05.3^{\prime \prime}$ & 7.6 & 123.9 & 34.0 & 2.3 & 2.2 & 1.6 & 13.0 & 4.2 \\
\hline 8 & 7 & 26 July 2017 & $69^{\circ} 02^{\prime} 47.8^{\prime \prime}$ & $20^{\circ} 51^{\prime} 46.3^{\prime \prime}$ & 8.2 & 211.1 & 63.0 & 1.9 & 2.0 & 0.8 & 23.1 & 8.1 \\
\hline 9 & 8 & 17 July 2009 & $69^{\circ} 02^{\prime} 59.5^{\prime \prime}$ & $20^{\circ} 51^{\prime} 51.8^{\prime \prime}$ & 8.1 & 125.6 & 61.6 & 1.4 & 2.4 & 1.3 & 25.4 & 8.7 \\
\hline 10 & 8 & 05 July 2010 & & & 7.1 & 116.2 & 41.9 & 0.8 & 1.8 & 0.8 & 17.5 & 4.9 \\
\hline 11 & 9 & 17 July 2009 & $69^{\circ} 03^{\prime} 09.7^{\prime \prime}$ & $20^{\circ} 51^{\prime} 31.4^{\prime \prime}$ & 7.3 & 245.0 & 159.8 & 1.6 & 3.2 & 1.5 & 47.2 & 19.9 \\
\hline 12 & 9 & 30 June 2010 & & & 7.4 & 172.6 & 73.0 & 1.1 & 2.3 & 1.0 & 24.7 & 0.1 \\
\hline 13 & 10 & 12 August 2008 & $69^{\circ} 02^{\prime} 58.0^{\prime \prime}$ & $20^{\circ} 49^{\prime} 39.3^{\prime \prime}$ & 5.7 & 13.0 & 0.8 & 0.5 & 0.2 & 0.1 & 0.2 & 0.1 \\
\hline 14 & 10 & 07 July 2009 & & & 6.8 & 12.7 & 1.4 & 1.1 & 1.3 & 0.4 & 2.5 & 0.2 \\
\hline 15 & 10 & 08 July 2010 & & & 7.0 & 7.0 & 0.9 & 0.4 & 0.5 & 0.1 & 1.4 & 0.1 \\
\hline 16 & 11 & 18 May 2008 & $69^{\circ} 05^{\prime} 14.9^{\prime \prime}$ & $20^{\circ} 45^{\prime} 33.4^{\prime \prime}$ & 7.2 & 22.8 & 1.4 & 2.1 & 1.5 & 0.4 & 1.8 & 0.4 \\
\hline 17 & 12 & 27 May 2008 & $69^{\circ} 05^{\prime} 08.6^{\prime \prime}$ & $20^{\circ} 47^{\prime} 20.5^{\prime \prime}$ & 7.3 & 16.7 & 1.0 & 1.5 & 1.0 & 0.5 & 1.6 & 0.3 \\
\hline
\end{tabular}




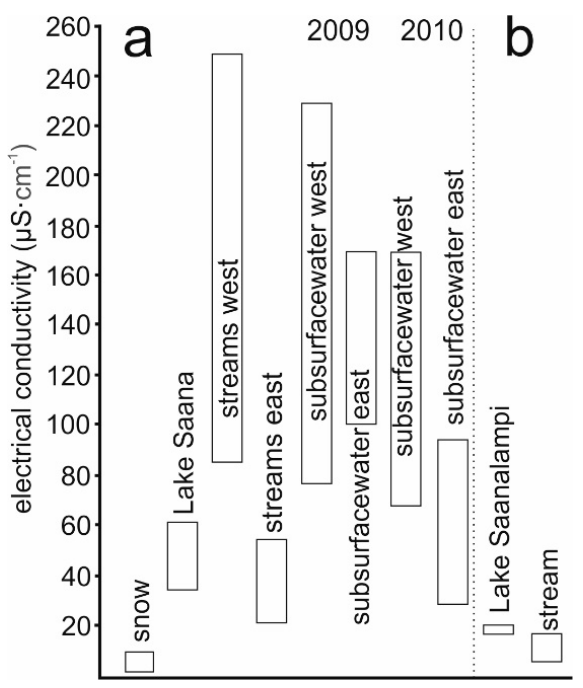

Figure 5. Values of electrical conductivity in streams and subsurface water on the catchments of lakes Saana (a) and Saanalampi catchment (b).

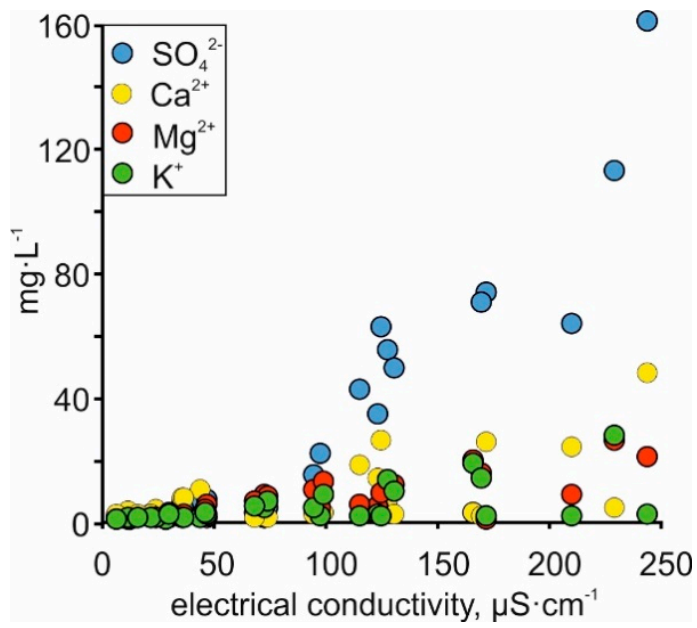

Figure 6. Variations of major ions in dependence on electrical conductivity in stream samples.

\subsection{Carbonate Dissolution}

In the Lake Saanalampi catchment (sampling point 10), above the dolomite layer, the $\mathrm{Mg}^{2+}$ and $\mathrm{Ca}^{2+}$ concentrations in stream water samples remained between 0.1 to 0.2 and 0.2 to $2.5 \mathrm{mg} \cdot \mathrm{L}^{-1}$, respectively, which are similar to their concentrations in the snow cover (average 0.1 and $0.9 \mathrm{mg} \cdot \mathrm{L}^{-1}$, respectively) [27]. The streams not only in the western part but all over the Lake Saana catchment had usually slightly higher $\mathrm{Mg}^{2+}$ and $\mathrm{Ca}^{2+}$ contents than precipitation (Table 3). Many previous studies have shown that even if a small proportion of the rock in a watershed contains carbonate, it could be an important factor controlling the chemical composition of the runoff $[46,47]$. Obviously, the dolomite is present not only close to Mount Saana, but over the entire Lake Saana catchment, probably as aeolian dust or till material in Quaternary sediments.

In the western part of the Lake Saana catchment, on the eastern slope of Mount Saana, where higher $\mathrm{SO}_{4}{ }^{2-}$ values have been detected, a clear relationship between $\mathrm{Mg}^{2+}, \mathrm{Ca}^{2+}$ and $\mathrm{SO}_{4}{ }^{2-}$ content can be seen (Figure 7). Dissolution of carbonate minerals can quickly neutralize the acidity produced from sulphide oxidation and the chemical weathering budget of the watershed becomes controlled by the carbonate mineral reactivity [30,34]. It seems that in the eastern part of the Lake Saana catchment carbonate dissolution is controlled by vegetation and diffusion of atmospheric $\mathrm{CO}_{2}$, but in the western part by pyrite oxidation (Figure 8). 


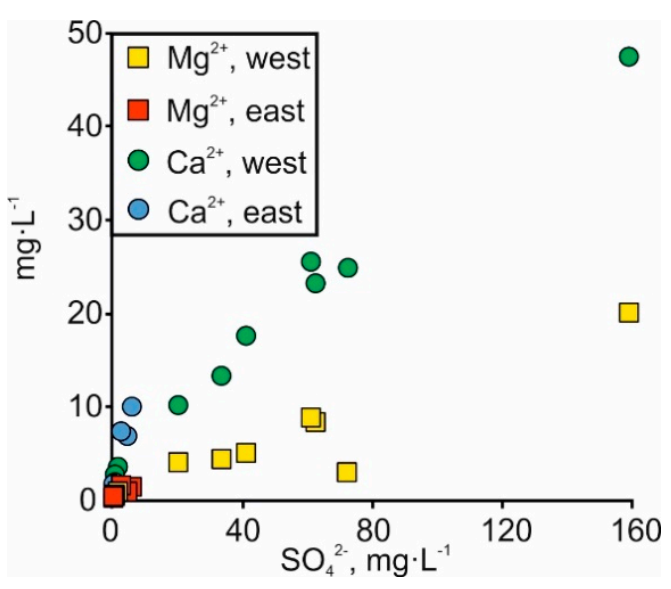

Figure 7. $\mathrm{Ca}^{2+}, \mathrm{Mg}^{2+}$ and $\mathrm{SO}_{4}{ }^{2-}$ variations in western and eastern streams on the catchment of Lake Saana.

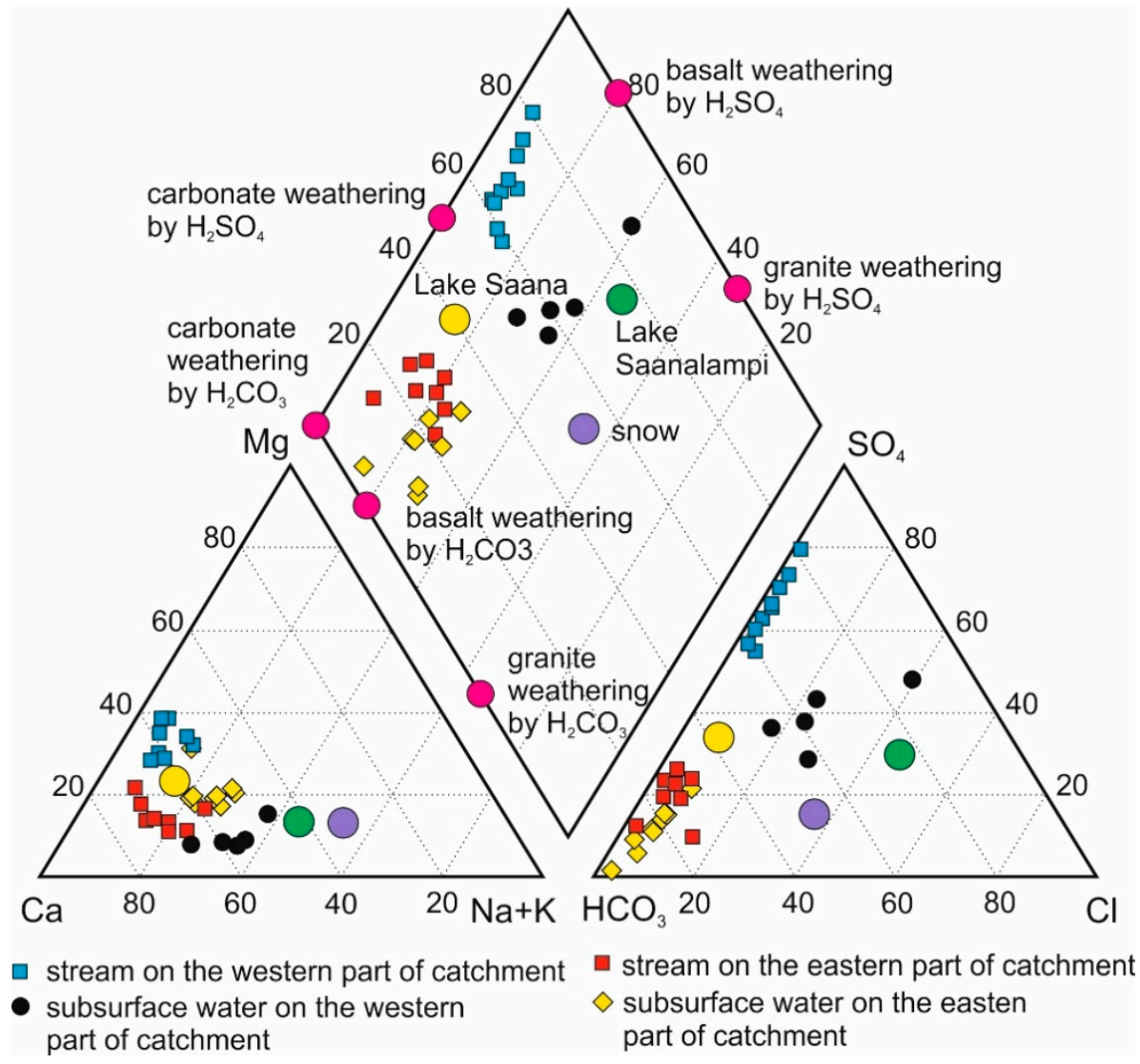

Figure 8. Piper diagram of Lake Saana catchment waters illustrating contributions from weathering of major rock types by carbonic acid and sulphuric acid after Spence and Telmer [33]. Chemical data of lakes is presented in the Supplementary Information B. Bicarbonate is calculated based on the charge balance of the solution.

The chemical data from subsurface water show similar relations between $\mathrm{SO}_{4}{ }^{2-}$ and $\mathrm{Ca}^{2+}$ to those of runoff in 2010. In 2009, when the groundwater table was lower, the situation in the eastern part of the catchment was different: $\mathrm{Ca}^{2+}$ reached similar concentrations to those in the western part of the catchment (Figure 9). The reason seems to be evaporative concentration, since $\mathrm{Cl}^{-}$content in the subsurface water has increased several times, although $\mathrm{SO}_{4}{ }^{2-}$ content has remained low (Table 2). The latter could be a result of anaerobic microbial oxidation of the organic material where bacteria have used $\mathrm{SO}_{4}{ }^{2-}$ as terminal electron acceptor [48-50]. The decomposition of organic material has probably also increased the amount of $\mathrm{CO}_{2}$ in the soil, which has facilitated the dissolution of carbonates. 


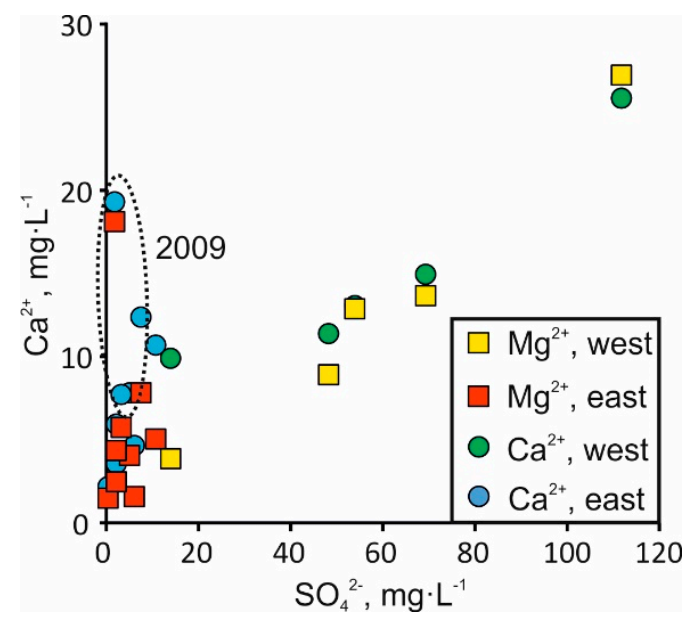

Figure 9. $\mathrm{Ca}^{2+}$ and $\mathrm{SO}_{4}{ }^{2-}$ variations in subsurface water on the catchment of Lake Saana.

\subsection{Silicate Weathering}

While $\mathrm{Cl}^{-}$content in stream water (average $1.2 \mathrm{mg} \cdot \mathrm{L}^{-1}$ ) was similar to that of snow (average $1.2 \mathrm{mg} \cdot \mathrm{L}^{-1}$ ) [27], $\mathrm{Na}^{+}$content in streams was slightly higher than in snow (average $3.1 \mathrm{mg} \cdot \mathrm{L}^{-1}$ and $2.1 \mathrm{mg} \cdot \mathrm{L}^{-1}$, respectively). Higher $\mathrm{Na}^{+}$concentration could be the result of higher dust input in summer compared to that of winter, because the surface is more open to aeolian denudation [51]. However, $\mathrm{Na}^{+}$is in good correlation with $\mathrm{K}^{+}$(Figure 10) and the concentrations of the latter are several times higher in streams (average $0.7 \mathrm{mg} \cdot \mathrm{L}^{-1}$ ) than in snow (average $0.1 \mathrm{mg} \cdot \mathrm{L}^{-1}$ ). Higher concentrations of $\mathrm{K}^{+}$in the arctic stream water compared to precipitation suggest that weathering reactions involved a silicate mineral $[2,7,34,52,53]$.

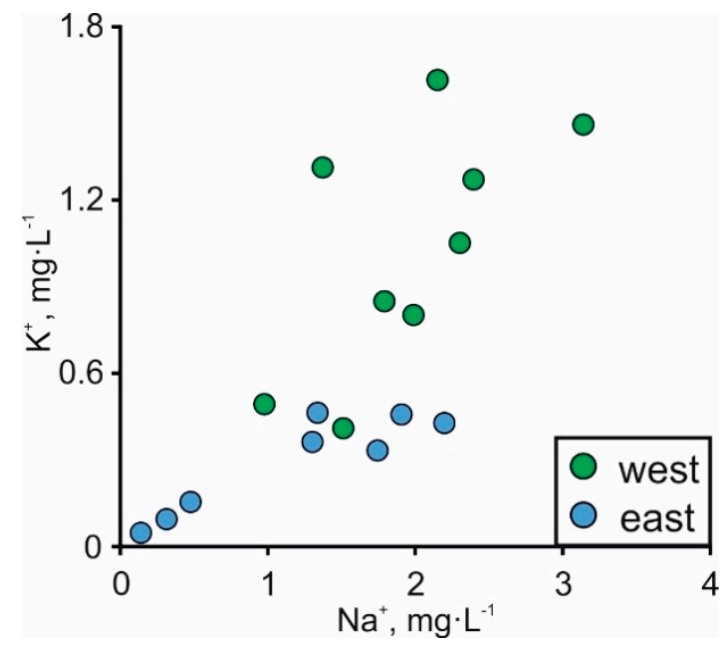

Figure 10. $\mathrm{Na}^{+}$and $\mathrm{K}^{+}$variations in streams.

Dissolution of silicates in natural waters is kinetically controlled $[1,2,7,30,54]$ and only flow paths of the highest residence times attain high concentrations of silicate weathering products [55]. However, Dragon and Marciniak, [12]; Tranter et al. [56]; Brown, [57] and Williams et al. [58] show that arctic stream water that is characterised by a similar flow distance (less than $1 \mathrm{~km}$ ) to that of streams in the Lake Saana catchment could already have been mineralised with similar $\mathrm{K}^{+}$and $\mathrm{Na}^{+}$contents. Anderson et al. [59] and Hall et al. [60] have suggested that weathering in cold regions is mostly limited by the availability of moisture, because ice formation may generate and propagate micro- or macro-cracks in rocks, and subsequent warming and thawing weaken or loosen the fractured rocks. The production of fresh mineral surfaces via physical weathering processes can greatly enhance silicate dissolution rates $[57,59,61-63]$. Although, freeze-thaw cycles alone fail to produce any measurable 
rock breakdown, a symbiotic relationship with geochemical processes like pyrite oxidation can enhance its effects considerably [64-66]. Moreover, pyrite oxidation also appears to be strongly dependent on earlier mechanical erosion $[34,43,67]$. Indeed, higher $\mathrm{K}^{+}$contents in the surroundings of Mount Saana are accompanied by higher $\mathrm{SO}_{4}{ }^{2-}$ values (Figure 11). It is possible that temperature fluctuations, the presence of aggressive $\mathrm{H}_{2} \mathrm{SO}_{4}$ and low salinity in springtime meltwater contribute to enhancing chemical weathering rates, which in turn could increase both $\mathrm{Na}^{+}$and $\mathrm{K}^{+}$concentrations in the Lake Saana catchment.

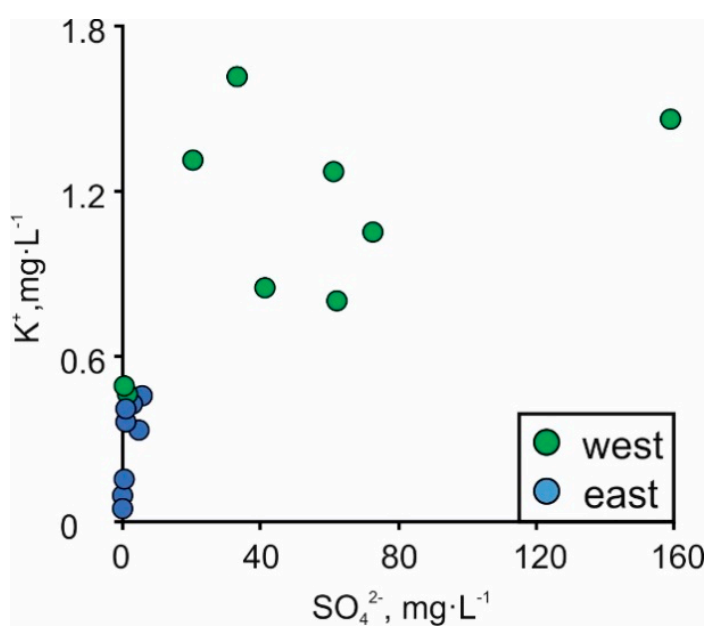

Figure 11. $\mathrm{K}^{+}$and $\mathrm{SO}_{4}{ }^{2-}$ variations in streams.

On the other hand, Beaulieu et al. [34] showed the negligible impact of sulphide oxidation on silicate weathering when carbonate minerals were present in the weathering profiles in the Mackenzie Basin. Within the current study, silicate weathering by sulphuric acid is believed to have occurred before the water had any contact with carbonate rocks, or that pyrite was oxidized after being in contact with dolomite minerals. The chemical data show the presence of dolomite all over the catchment, which is why the possibility of silicate weathering having occurred at the foot of Mount Saana can probably be excluded. Therefore, much of $\mathrm{K}^{+}$and $\mathrm{Na}^{+}$in stream water in the western part of the catchment could have originated from the top of Mount Saana, where no limestone is present. It could suggest that pyrite is represented not only in the lower nappes at the foot of Mount Saana, but also at the top of the mount (Figure 12). Additionally, Mount Saana with its cracks and fractures could also be an important water reservoir feeding the aforementioned streams, because fractured or epikarst sub-systems are known to act as an important water storage and a mixing element [68-70]. It would also allow longer contact time for water-rock interaction to produce silicate weathering.

The effect of pyrite oxidation on dissolution of silicates was not as obvious as on carbonates in subsurface water, although the $\mathrm{pH}$ was much lower in the latter compared to that in streams (6.3-7.4 and 6.4-8.5 respectively; Tables 2 and 3). The contents of $\mathrm{Na}^{+}, \mathrm{K}^{+}$and $\mathrm{SO}_{4}{ }^{2-}$ in subsurface water were just slightly higher than in streams, but $\mathrm{Ca}^{2+}$ and $\mathrm{Mg}^{2+}$ concentrations were lower. Subsurface water has most likely been in contact with silicate claystones, which under the Quaternary sediments are well represented in the catchment. As mentioned before, sulphur (pyrite) contents there can be relatively high, suggesting silicate weathering over the catchment. It is possible that some meltwater infiltrates trough the Mount Saana bedrock and later percolates to and flows down the slope of the mount (Figure 12). If the infiltrated water still contains dissolved $\mathrm{O}_{2}$ after penetrating the dolomite layer, pyrite oxidation can also occur in claystone. A common remnant of pyrite oxidation, haematite, is widely spread on the slope of Mount Saana (Figure 12), which supports this view. The infiltration coefficients of local rocks and aeration conditions atop Mount Saana are unknown and the idea of the inner water flow with its geochemical effect for the moment is rather speculative. At any rate, the results show that the connection between stream and subsurface water is weak and a retention time of the latter quite long. 


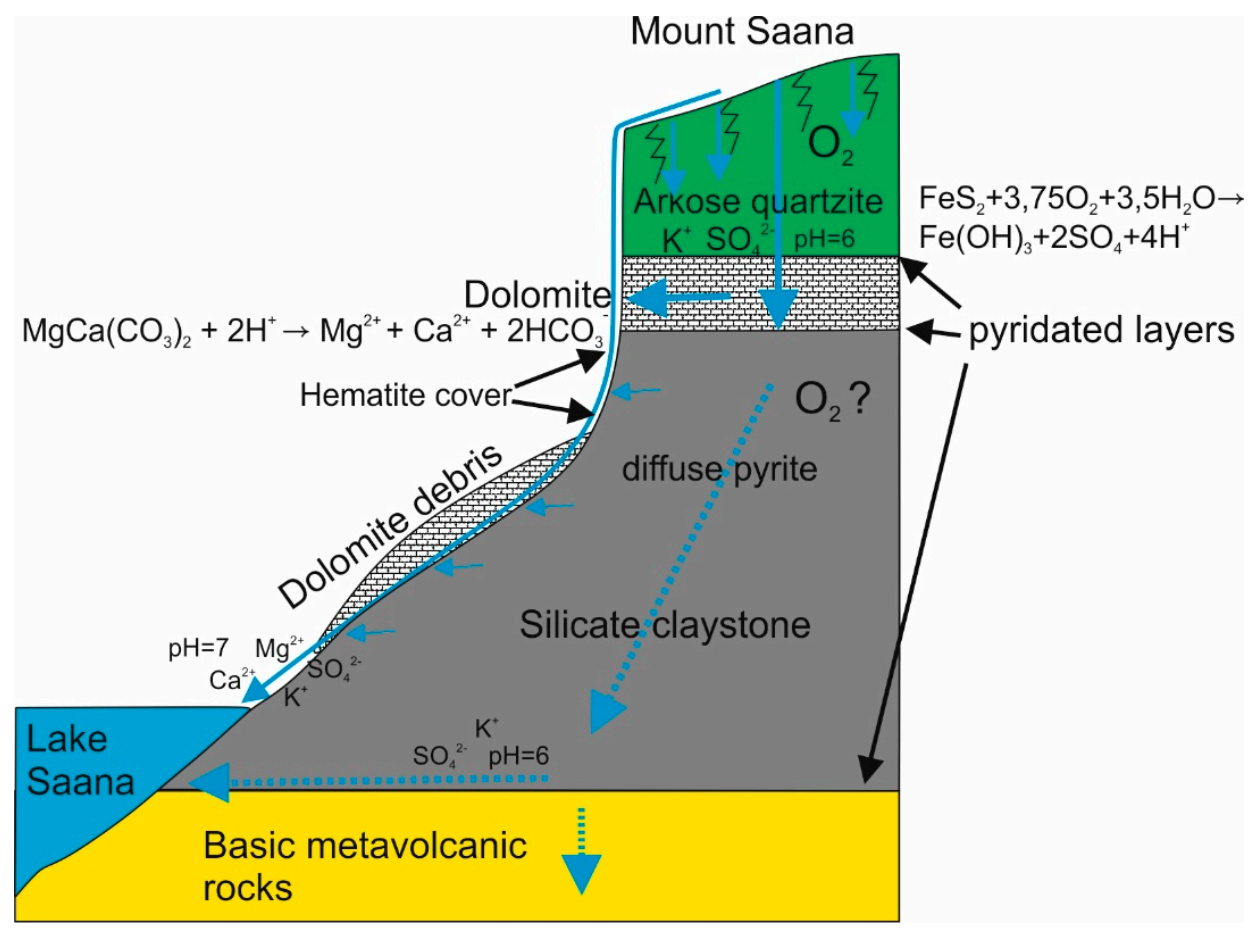

Figure 12. A conceptual model of the geochemical situation on the eastern slope of Mount Saana with the main directions of water flow paths. The totted arrows indicate possible water flow.

\subsection{Stream Water Input into the Surroundings}

Although the salinity in Lake Saanalampi (5.3 and $6.86 \mu \mathrm{S} \cdot \mathrm{cm}^{-1}$ ) was higher than in local streams, the difference is small (Figure $5 \mathrm{~b}$ ) and it can be concluded that the lake's chemical composition is mainly controlled by atmospheric input. The lakes feed mainly on springtime meltwater and thereby the chemical composition of snow directly affects the conditions of the lake.

Lake Saana waters proved to be quite diluted $\left(10\right.$ to $\left.25 \mu \mathrm{S} \cdot \mathrm{cm}^{-1}\right)$, while electrical conductivity was higher in most streams and subsurface waters. Only electrical conductivity of the lake and its northern influx was similar (Figure 5a). Meltwater probably predominates in early spring, because $\delta^{18} \mathrm{O}$ composition of surface water of the lake is clearly more depleted in springtime $(-15.8 \%$ o $)$ [19]. These values match the $\delta^{18} \mathrm{O}$ composition of the average snow cover $(-14.7 \%$ o) [27]. For the rest of the year, the northern influx could be in control of the lake's chemical composition. Still, it is important to point out that earlier monitoring of the lake's chemical composition has only been done in the central, deepest part of the lake. Based on the results, which show a difference in stream water chemistry between the eastern and western parts of the catchment, chemical variation in the marginal areas of the lake could be expected to occur in the spring when the lake is still covered by ice and wind mixing is lacking. The content of $\mathrm{SO}_{4}{ }^{2-}$ in stream water was relatively high, but there is no clear reason to link $\mathrm{pH}$ fluctuation in local lakes to pyrite oxidation, although the latter produces lower $\mathrm{pH}$ values. The results showed that a higher $\mathrm{SO}_{4}{ }^{2-}$ content was accompanied by higher $\mathrm{pH}$ values (Table 3), which obviously come from buffering of carbonate rocks. Still, a speculative possibility remains that there could also be a flow through the bedrock of Mount Saana bringing the acidic water into the lake. This inflow would be the heaviest in spring when snow melt creates floods (Figure 12).

Several studies have shown that bedrock geochemistry strongly influences the soil's nutrient content and, at the same time, its biodiversity [71]. However, the plants obtain nutrients not directly from the soil but from the soil fluids. This study has shown that chemical composition of the fluid does not match the geochemical signal from the soil. Although relevant studies on the relation between bedrock geochemistry and biodiversity have been conducted on the Lake Saana catchment (Systra, 2010; Kauhanen, 2013; Kumar et al., 2016) [72-74], these are not detailed enough to understand whether 
hydrochemical differences between the western and eastern parts of the catchment have affected local biodiversity.

\section{Conclusions}

The investigation in the Arctic Kilpisjärvi area stresses the importance of spatial variability of stream water chemistry even on a small territory. The obtained results from the Lake Saanalampi catchment show that rock weathering can be quite limited and the chemistry of runoff and lake waters similar to precipitation (snow cover). Inversely, the results in the Lake Saana catchment demonstrate that Arctic conditions do not preclude intense chemical weathering where conditions are favourable.

Although pyrite locations have not been conclusively identified in local rocks, the suggested weathering hypothesis would require their presence. Based on earlier visual observations, it can be supposed that sulphur may be related to claystone outcropping widely at the base section of Mount Saana. The results of the current study show that essential pyritization has occurred in nappes on top of Mount Saana. The contribution from the Archaean basement seems to be negligible but cannot be ruled out completely, since there is local sulphide mineralization in intermediate and basic rocks. Apparently, pyrite spread in the catchment can be related to claystone and tectonic zones at the foot and on top of Mount Saana.

The study shows that local conditions, when sulphide minerals are present, create a chemically aggressive environment in the Kilpisjärvi area, which in some sites could cause particularly high chemical weathering rates compared to other Arctic-alpine areas. The results show that the buffering of $\mathrm{H}_{2} \mathrm{SO}_{4}$ controls both carbonate and silicate weathering in the western part of the catchment. On the rest of the research area, the dissolution of dolomite is controlled by partial pressure of $\mathrm{CO}_{2}$ and the weathering rate of silicates has stayed several times lower than in the western part of the catchment. No clear connection between pyrite oxidation and $\mathrm{pH}$ fluctuation in local lakes could be seen, which supports earlier views that it is mostly precipitation that controls lake water chemistry in the Kilpisjärvi area. Still, it should be pointed out that differences in the chemical composition of streams could create ecologically different conditions for plants and microorganisms in spite of geochemical similarity of the surface rock.

Supplementary Materials: The following are available online at http://www.mdpi.com/2076-3263/9/4/174/s1, Supplementary A: Representative XRD patterns of subsurface samples (Table 1); Supplementary B: Chemical composition of lake water in the Kilpisjärvi area in 2008 to 2010.

Author Contributions: Conceptualization, V.R.; Data curation, V.R., J.I. and A.S.; Formal analysis, J.I.; Funding acquisition, E.K.; Investigation, V.R., E.K., J.I. and A.S.; Project administration, E.K.; Resources, E.K.; Visualization, V.R. and S.H.; Writing-original draft, V.R. and A.S.

Funding: This research was funded by the LAPBIAT (The research Infrastructure Lapland Atmosphere-Biosphere Facility) grant to EK and by the contract No 10.1/8.1/11/488-6 between the Ministry of Education and Research of Estonia and Tallinn University of Technology.

Acknowledgments: We thank Helle Pohl-Raidla for language corrections. We are indebted to the Finnish Meteorological Institute for providing the weather data and to the Institute of Ecology and Earth Sciences in the Department of Geology at University of Tartu for their technical support. In the fieldwork participated also the winners of all-Estonian high school students Polar Knowledge Contest 2017 during their expedition to North Scandinavia: Maria Huntsaar, Carmen Kuusk, Sten Arthur Laane, Siim Lilleoja, Adel Müürsepp. The manuscript was significantly improved by constructive comments of three anonymous reviewers.

Conflicts of Interest: The authors declare no conflict of interest.

\section{References}

1. Berner, K.E.; Berner, R.A. Global Environment: Water, Air and Geochemical Cycles; Princeton University Press: Upper Saddle River, NJ, USA, 1996; 376p.

2. Stutter, M.I.; Billett, M.F. Biogeochemical controls on streamwater and soil solution chemistry in a High Arctic environment. Geoderma 2003, 113, 127-146. [CrossRef] 
3. Lerman, A.; $\mathrm{Wu}$, L.; Mackenzie, F.T. $\mathrm{CO}_{2}$ and $\mathrm{H}_{2} \mathrm{SO}_{4}$ consumption in weathering and material transport to the ocean, and their role in the global carbon balance. Mar. Chem. 2007, 106, 326-350. [CrossRef]

4. Calmels, D.; Gaillardet, J.; François, L. Sensitivity of carbonate weathering to soil $\mathrm{CO}_{2}$ production by biological activity along a temperate climate transect. Chem. Geol. 2014, 390, 74-86. [CrossRef]

5. Giesler, R.; Lyon, S.W.; Mörth, C.-M.; Karlsson, J.; Karlsson, E.M.; Jantze, E.J.; Destouni, G.; Humborg, C. Catchment-scale dissolved carbon concentrations and export estimates across six subarctic streams in northern Sweden. Biogeosciences 2014, 11, 525-537. [CrossRef]

6. Millot, R.; Gaillardet, J.; Dupré, B.; Allégre, C.J. Northern latitude chemical weathering rates: Clues from the Mackenzie River Basin, Canada. Geochim. Cosmochim. Acta 2003, 67, 1305-1329. [CrossRef]

7. Thorn, C.E.; Darmody, R.G.; Dixon, J.C.; Schlyter, P. The chemical weathering regime of Kärkevagge, artic-alpine Sweden. Geomorphology 2001, 41, 37-52. [CrossRef]

8. Darmody, R.G.; Thorn, C.E.; Harder, R.L.; Schlyter, J.P.L.; Dixon, J.C. Weathering implications of water chemistry in an arctic-alpine environment, northern Sweden. Geomorphology 2000, 34, 89-100. [CrossRef]

9. Darmody, R.G.; Thorn, C.E.; Allen, C.E. Chemical weathering and boulder mantles, Kärkevagge, Swedish Lapland. Geomorphology 2005, 67, 159-170. [CrossRef]

10. Beylich, A.A.; Kolstrup, E.; Linde, N.; Pedersen, L.B.; Thyrsted, T.; Gintz, D.; Dynesius, L. Assessment of chemical denudation rates using hydrological measurements, water chemistry analysis and electromagnetic geophysical data. Permafr. Periglac. Process. 2003, 14, 387-397. [CrossRef]

11. Beylich, A.A.; Kneisel, C. Sediment budget and relief development in Hrafndalur, sub-Arctic oceanic eastern Iceland. Arct. Antarct. Alp. Res. 2009, 41, 3-17. [CrossRef]

12. Dragon, K.; Marciniak, M. Chemical composition of groundwater and surface water in the Arctic environment (Petuniabukta region, central Spitsbergen). J. Hydrol. 2010, 386, 160-172. [CrossRef]

13. Beylich, A.A. Mass transfers, sediment budgets and relief development in cold environments: Results of long-term geomorphologic drainage basin studies in Iceland, Swedish Lapland and Finnish Lapland. Zeitschrift für Geomorphologie N.F. 2011, 55, 145-174. [CrossRef]

14. Beylich, A.A.; Laute, K. Spatial variations of surface water chemistry and chemical denudation in the Erdalen drainage basin, Nordfjord, western Norway. Geomorphology 2012, 167, 77-90. [CrossRef]

15. Dixon, J.C.; Thorn, C.E. Chemical weathering and landscape development in mid-latitude alpine environments. Geomorphology 2005, 67, 127-145. [CrossRef]

16. Reynolds, R.C., Jr. Clay mineral formation in an alpine environment. Clays Clay Miner. 1971, 19, 361-374. [CrossRef]

17. Caine, N.; Thurman, E.M. Temporal and spatial variations in the solute content of an alpine stream, Colorado Front Range. Geomorphology 1990, 4, 55-72. [CrossRef]

18. Dixon, J.C.; Darmody, R.G.; Schlyter, P.; Thorn, C.E. Preliminary investigation of geochemical process responses to potential environmental change in Kärkevagge, Northern Scandinavia. Geografiska Annaler 1995, 77A, 259-267. [CrossRef]

19. Forsström, L.; Sorvari, S.; Rautio, M.; Sonninen, E.; Korhola, A. Changes in physical and chemical limnology and plankton during the Spring melt period in a subarctic Lake. Int. Rev. Hydrobiol. 2007, 92, 301-325. [CrossRef]

20. Sorvari, S.; Rautio, M.; Korhola, A. Seasonal dynamics of the subarctic Lake Saanajärvi in Finnish Lapland. Verheissungen Int. Ver. Gesamten Limnol. 2000, 27, 507-512. [CrossRef]

21. Molot, L.A.; Dillon, P.J.; Lazerte, B.D. Factors affecting alkalinity concentrations of streamwater during snowmelt in Central Ontario. Can. J. Fish. Aquat. Sci. 1989, 46, 1658-1666. [CrossRef]

22. Bishop, K.; Pettersson, C. Organic carbon in the boreal spring flood from adjacent subcatchments. Environ. Int. 1996, 22, 535-540. [CrossRef]

23. Moiseenko, T.; Kudrjavzeva, L.; Rodyshkin, I. The episodic acidification of small streams in the spring flood period of industrial polar region, Russia. Chemosphere 2001, 42, 45-50. [CrossRef]

24. Petrone, K.; Buffam, I.; Laudon, H. Hydrologic and biotic control of nitrogen export during snowmelt: a combined conservative and reactive tracer approach. Water Resour. Res. 2007, 43, W06420. [CrossRef]

25. Laudon, H.; Westling, O.; Bishop, K. Cause of $\mathrm{pH}$ decline in stream water during spring melt runoff in northern Sweden. Can. J. Fish. Aquat. Sci. 2000, 57, 1888-1900. [CrossRef] 
26. De Caritat, P.; Hall, G.; Gislason, S.; Belsey, W.; Braun, M.; Goloubeva, N.I.; Olsen, H.K.; Scheie, J.O.; Vaive, J.E. Chemical composition of arctic snow: concentration levels and regional distribution of major elements. Sci. Total Environ. 2005, 336, 183-199. [CrossRef] [PubMed]

27. Raidla, V.; Kaup, E.; Ivask, J. Factors affecting the chemical composition of snowpack in the Kilpisjärvi area of North Scandinavia. Atmos. Environ. 2015, 118, 211-218. [CrossRef]

28. Korhola, A.; Sorvari, S.; Rautio, M.; Appleby, P.G.; Dearing, J.A.; Hu, Y.; Rose, N.; Lami, A.; Cameron, N.G. A multi-proxy analysis of climate impacts on the recent development of subarctic Lake Saanajärvi in Finnish Lapland. J. Paleolimnol. 2002, 28, 59-77. [CrossRef]

29. Carminati, E. Incremental strain analysis using two generations of syntectonic coaxial fibres: an example from the Monte Marguareis Briançonnais Cover nappe (Ligurian Alps, Italy). J. Struct. Geol. 2001, 23, 1441-1456. [CrossRef]

30. Anderson, S.P.; Drever, J.I.; Frost, C.D.; Holden, P. Chemical weathering in the foreland of a retreating glacier. Geochim. Cosmochim. Acta 2000, 64, 1173-1189. [CrossRef]

31. Cooper, R.J.; Wadham, J.L.; Trantera, M.; Hodgkinsb, R.; Peters, N.E. Groundwater hydrochemistry in the active layer of the proglacial zone, Finsterwalderbreen, Svalbard. J. Hydrol. 2002, 269, 208-223. [CrossRef]

32. Gaillardet, J.; Millot, R.; Dupré, B. Chemical denudation rates of the western Canadian orogenic belt: The Stikine terrane. Chem. Geol. 2003, 201, 257-259. [CrossRef]

33. Spence, J.; Telmer, $\mathrm{K}$. The role of sulfur in chemical weathering and atmospheric $\mathrm{CO}_{2}$ fluxes: evidence from major ions, $\delta^{13} \mathrm{C}_{\mathrm{DIC}}$, and $\delta^{34} \mathrm{~S}_{\mathrm{SO} 4}$ in rivers of the Canadian Cordillera. Geochim. Cosmochim. Acta 2005, 69, 5441-5458. [CrossRef]

34. Beaulieu, E.; Goddéris, Y.; Labat, D.; Roelandt, C.; Calmels, D.; Gaillardet, J. Modeling of water-rock interaction in the Mackenzie basin: Competition between sulfuric and carbonic acids. Chem. Geol. 2011, 289, 114-123. [CrossRef]

35. Järvinen, A. Basic climatological data on the Klipisjärvi area, NW Finnish Lapland. Kilpisjärvi Notes 1987, 10, 1-16.

36. Drebs, A.; Nordlund, A.; Karlsson, P.; Helminen, J.; Rissanen, P. Climatological statistics of Finland 1971-2000. In Climatic Statistics of Finland 2002: 1; Finnish Meteorological Institute: Helsinki, Finland, 2002; p. 99.

37. Atlas of Finland. Geology, 1: 200000 Geological map of Finland. National Board of Survey, Geographical Society of Finland, 1986. Folio 123-126. Available online: http://gtkdata.gtk.fi/Kalliopera/index.html (accessed on 14 March 2019).

38. Männistö, M.K.; Tiirola, M.; Häggblom, M.M. Bacterial communities in Arctic fjelds of Finnish Lapland are stable but highly pH-dependent. FEMS Microbiol. Ecol. 2007, 59, 452-465. [CrossRef] [PubMed]

39. Kohout, T.; Bućko, M.S.; Rasmus, K.; Leppäranta, M.; Matero, I. Non-Invasive Geophysical Investigation and Thermodynamic Analysis of a Palsa in Lapland, Northwest Finland. Permafr. Periglac. Process. 2014, 25, 45-52. [CrossRef]

40. King, L.; Seppälä, M. Permafrost Thickness and Distribution in Finnish Lapland-Results of Geoelectrical Soundings. Polarforschung 1987, 57, 127-147.

41. Vanhala, H.; Lintinen, P.; Ojala, A. Electrical resistivity study of permafrost on Ridnitšohkka fell in northwest Lapland, Finland. Geophysica 2009, 45, 103-118.

42. Finnish Meteorological Institute. The Finnish Meteorological Institute's open data. Available online: https://en.ilmatieteenlaitos.fi/open-data (accessed on 1 August 2018).

43. Calmels, D.; Gaillardet, J.; Brenot, A.; France-Lanord, C. Sustained sulfide oxidation by physical erosion processes in the Mackenzie River basin: climatic persperctives. Geology 2007, 35, 1003-1006. [CrossRef]

44. Szynkiewicz, A.; Borrok, D.M.; Skrzypek, G.; Rearick, M.S. Isotopic studies of the Upper and Middle Rio Grande. Part 1-Importance of sulfide weathering in the riverine sulfate budget. Chem. Geol. 2015, 411, 323-335. [CrossRef]

45. Appelo, C.; Postma, D. Geochemistry, Groundwater and Pollution; Balkema: Rotterdam, The Netherlands, 2004; p. 683.

46. Jacobson, A.D.; Blum, J.D.; Walter, L.M. Reconciling the elemental and Sr isotope composition of Himalayan weathering fluxes: Insights from the carbonate geochemistry of stream waters. Geochim. Cosmochim. Acta 2002, 66, 3417-3429. [CrossRef]

47. Arendt, C.A.; Stevenson, E.I.; Aciego, S.M. Hydrologic controls on radiogenic Sr in meltwater from an alpine glacier system: Athabasca Glacier, Canada. Appl. Geochem. 2016, 69, 42-49. [CrossRef]

48. Jørgensen, B.B.; Postgate, J.R. Ecology of the bacteria of the sulphur cycle with special reference to anoxic-oxic interface environments. Philos. Trans. R. Soc. Lond. 1982, 298, 543-561. [CrossRef]

49. Wadham, J.L.; Bottrell, S.; Tranter, M.; Raiswell, R. Stable isotope evidence for microbial sulphate reduction at the bed of a polythermal high Arctic glacier. Earth Planet. Sci. Lett. 2004, 219, 341-355. [CrossRef] 
50. Brunner, B.; Bernasconi, S.M.; Kleikemper, J.; Schroth, M.H. A model for oxygen and sulfur isotope fractionation in sulfate during bacterial sulfate reduction processes. Geochim. Cosmochim. Acta 2005, 69, 4773-4785. [CrossRef]

51. Geng, H.; Jiyeon, R.; Jung, H.-J.; Chung, H.; Ahn, K.-H.; Ro, C.-U. Single-particle characterization of summertime Arctic aerosols collected at Ny-Ålesund, Svalbard. Environ. Sci. Technol. 2010, 44, 2348-2353. [CrossRef]

52. Dixon, J.C.; Thorn, C.E.; Darmody, R.G.; Campbell, S.W. Weathering rinds and rock coatings from an Arctic alpine environment, northern Scandinavia. Geol. Soc. Am. Bull. 2002, 114, 226-238. [CrossRef]

53. White, A.F.; Schulz, M.S.; Vivit, D.V.; Blum, A.E.; Stonestrom, D.A.; Harden, J.W. Chemical weathering rates of a soil chronosequence on granitic alluvium: III. Hydrochemical evolution and contemporary solute fluxes and rates. Geochim. Cosmochim. Acta 2005, 69, 1975-1996. [CrossRef]

54. Drever, J.I. The Geochemistry of Natural Waters, 3rd ed.; Prentice Hall: Upper Saddle River, NJ, USA, 1998.

55. Hodson, A.; Tranter, M.; Gurnell, A.; Clark, M.; Hagen, J.O. The hydrochemistry of Bayelva, a high Arctic proglacial stream in Svalbard. J. Hydrol. 2002, 257, 91-114. [CrossRef]

56. Tranter, M.; Brown, G.H.; Raiswell, R.; Sharp, M.J.; Gurnell, A.M. A conceptual model of solute acquisition by alpine glacial meltwaters. J. Glaciol. 1993, 39, 573-581. [CrossRef]

57. Brown, G.H. Glacier meltwater hydrochemistry. Appl. Geochem. 2002, 17, 855-883. [CrossRef]

58. Williams, M.W.; Knauf, M.; Caine, N.; Liu, F.; Verplanck, P.L. Geochemistry and source waters of rock glacier outflow, Colorado Front Range. Permafr. Periglac. Process. 2006, 17, 13-33. [CrossRef]

59. Anderson, S.P.; Drever, J.I.; Humphrey, N.F. Chemical weathering in glacial environments. Geology 1997, $25,399-402$. [CrossRef]

60. Hall, K.; Thorn, C.E.; Matsuoka, N.; Prick, A. Weathering in cold regions: some thoughts and perspectives. Prog. Phys. Geogr. 2002, 26, 577-603. [CrossRef]

61. Matsuoka, N.; Moriwaki, K.; Hirakawa, K. Field experiments on physical weathering and wind erosion in an Antarctic cold desert. Earth Surf. Process. Landf. 1998, 21, 687-699. [CrossRef]

62. Anderson, S.P. Biogeochemistry of glacial landscape systems. Annu. Rev. Earth Planet. Sci. 2007, 35, 375-399. [CrossRef]

63. Marra, K.R.; Madden, M.E.E.; Soreghan, G.S.; Hall, B.L. BET surface area distributions in polar stream sediments: Implications for silicate weathering in a cold-arid environment. Appl. Geochem. 2015, 52, 31-42. [CrossRef]

64. Anderson, S.P.; Dietrich, W.E.; Brimhall, G.H. Weathering profiles, mass-balance analysis, and rates of solute loss: linkages between weathering and erosion in a small, steep catchment. Geol. Soc. Am. Bull. 2002, 114, 1143-1158. [CrossRef]

65. Yde, J.C.; Riger-Kusk, M.; Christiansen, H.H.; Knudsen, N.T.; Umlum, O. Hydrochemical characteristics of bulk meltwater from an entire ablation season, Longyearbreen, Svalbard. J. Glaciol. 2008, 54, $259-272$. [CrossRef]

66. Klaminder, J.; Grip, H.; Mörth, C.-M.; Laudon, H. Carbon mineralization and pyrite oxidation in groundwater: Importance for silicate weathering in boreal forest soils and stream base-flow chemistry. Appl. Geochem. 2011, 26, 319-325. [CrossRef]

67. Heidel, C.; Tichomirowa, M.; Junghans, M. The influence of pyrite grain size on the final oxygen isotope difference between sulphate and water in aerobic pyrite oxidation experiments. Isot. Environ. Health Stud. 2009, 45, 321-342. [CrossRef]

68. Aquilina, L.; Ladouche, B.; Dörfliger, N. Recharge processes in karstic systems investigated through the correlation of chemical and isotopic composition of rain and spring-waters. Appl. Geochem. 2005, 20, 2189-2206. [CrossRef]

69. Mueller, M.H.; Weingartner, R.; Alewell, C. Importance of vegetation, topography and flow paths for water transit times of base flow in alpine headwater catchments. Hydrol. Earth Syst. Sci. 2013, 17, 1661-1679. [CrossRef]

70. Genty, D.; Labuhn, I.; Hoffmann, G.; Danis, P.A.; Mestre, O.; Bourges, F.; Wainer, K.; Massault, M.; Van Exter, S.; Régnier, E.; et al. Rainfall and cave water isotopic relationships in two South-France sites. Geochim. Cosmochim. Acta 2014, 131, 323-343. [CrossRef]

71. Lenoir, J.; Gégout, J.-C.; Guisan, A.; Vittoz, P.; Wohlgemuth, T.; Zimmermann, N.E.; Dullinger, S.; Pauli, H.; Willner, W.; Grytnes, J.-A.; et al. Cross-scale analysis of the region effect on vascular plant species diversity in southern and northern European mountain ranges. PLoS ONE 2010, 5, e15734. [CrossRef] [PubMed] 
72. Systra, Y.J. Bedrock and Quaternary sediment geochemistry and biodiversity in Eastern Fennoscandia and Estonia. For. Stud./Metsanduslikud Uurimused 2010, 53, 35-52. [CrossRef]

73. Kauhanen, H.O. Mountains of Kilpisjärvi host an abundance of threatened plants in Finnish Lapland. Bot. Pac. 2013, 2, 43-52. [CrossRef]

74. Kumar, M.; Männistö, M.K.; van Elsas, J.D.; Nissinen, R.M. Plants impact structure and function of bacterial communities in Arctic soils. Plant Soil 2016, 399, 319-332. [CrossRef] 